Article

\title{
Cornus macrophylla, the Antibacterial Activity of Organic Leaf Extracts and the Characterization of the More Lipophilic Components by GC/MS
}

\author{
Muhammad Akbar ${ }^{1, *}$, Usman Ali ${ }^{1}$, Tayyaba Khalil ${ }^{1}$, Muhammad Sajjad Iqbal ${ }^{1}$, Awais Amin ${ }^{1}$, \\ Rehan Naeem ${ }^{2}$, Abdul Nazir ${ }^{3}{ }^{10}$, Hafiz Muhammad Waqas ${ }^{1}$, Zohaib Aslam ${ }^{1}$, Faisal Iqbal Jafri ${ }^{1}$, \\ Nazir Aslam ${ }^{1}$ and Safeer Akbar Chohan ${ }^{1}$ \\ 1 Department of Botany, University of Gujrat, Gujrat 50700, Pakistan; usmanbutt874@gmail.com (U.A.); \\ tayyaba.khalil@uog.edu.pk (T.K.); drsajjad.iqbal@uog.edu.pk (M.S.I.); awaisamin043@gmail.com (A.A.); \\ vk6296717@gmail.com (H.M.W.); mirzathecupid74@gmail.com (Z.A.); faisal.bhs@gmail.com (F.I.J.); \\ nazirmbdin@gmail.com (N.A.); meriuog@gmail.com (S.A.C.) \\ 2 Department of Biotechnology and Genetic Engineering, Kohat University of Science and Technology, \\ Kohat 26000, Khyber Pakhtunkhwa, Pakistan; gulerehan@gmail.com \\ 3 Department of Environmental Sciences, COMSATS University Islamabad, Abbottabad Campus, Tobe Camp, \\ Abbottabad 22060, Khyber Pakhtunkhwa, Pakistan; abdulnazeer@cuiatd.edu.pk \\ * Correspondence: makbarpu@gmail.com; Tel.: +92-333-7645058
}

Academic Editors: Anna Andolfi, Maria Michela Salvatore and Francesca Mancianti Received: 31 March 2020; Accepted: 3 May 2020; Published: 21 May 2020

\begin{abstract}
In the present study, the antibacterial activity of Cornus macrophylla was examined. Organic solvent extracts of leaves were prepared using methanol, $n$-hexane, chloroform, and ethyl acetate. Antibacterial activity was examined by using a $100 \mathrm{mg} / \mathrm{mL}$ extract concentration. Penicillin was kept as a positive control while dimethyl sulfoxide was taken as a negative control. Methanolic extract exhibited a 21.5, 36.3, 25.3, and $23.7 \mathrm{~mm}$ inhibition zone diameter (IZD); $n$-hexane showed a 33, 40, 32.8, and $28.7 \mathrm{~mm}$ IZD; chloroform showed a 18.8, 29, 22.3, and 21.6 mm IZD; and ethyl acetate showed a $23.5,30.2,30$, and $22.3 \mathrm{~mm}$ IZD against Erwinia carotovora, Pseudomonas syringae, Ralstonia solanacearum, and Xanthomonas axonopodis, respectively. The $n$-hexane extract revealed high antibacterial activity against all bacterial species as compared with methanolic, chloroform, and ethyl acetate extract. Gas Chromatography Mass Spectrometry (GC/MS) analysis of $n$-hexane extract depicted the presence of 55 compounds. Out of these compounds, one compound, identified as $\alpha$-amyrin (Mol. wt $=426$ ), exhibited the maximum peak area (32.64\%), followed by A'-Neogammacer-22(29)-en-3-ol, acetate, (3.beta.,21.beta.)- (Mol. wt $=468$ ) and $\beta$-amyrin (Mol. wt $=426$ ) having peak areas of 25.97 and $6.77 \%$, respectively. It was concluded that the antibacterial activity observed during the present investigation may be due to these compounds.
\end{abstract}

Keywords: $\alpha$-amyrin; antibacterial activity; Cornus macrophylla; GC/MS

\section{Introduction}

Plants are a valuable source of bioactive compounds due to the production of secondary metabolites. Secondary metabolites of plants show antimicrobial activity against a number of pathogens $[1,2]$. The extracts of plants are also used for treatment of serious diseases [3]. For the maintenance of quality and quantity of food, there is a need to control plant diseases caused by various pathogens. At present, the most reliable method for controlling bacterial pathogens is the use of synthetic/chemical pesticides. Although pesticides are helpful to crops, they have negative impacts on biodiversity, pollute the environment [4,5], and cause health problems [6,7]. Also, bactericidal application kills microbes that help plants defend against pathogens [8]. Moreover, numerous pathogens have developed resistance 
against numerous synthetic/commercial antibacterial compounds. These negative effects of synthetic chemicals have increased the interest of researchers in exploring natural biodegradable antimicrobials that could be effective alternatives to synthetic chemicals [9-11].

Approximately 20,000 plants around the world have medicinal activities; these plants have different bioactive compounds [12]. These bioactive compounds have antimicrobial activities and control the attack of plant pathogens on crops [13]. Plants have been studied widely due to their potent bioactive compounds and recent studies showed that different parts of plant extracts have antimicrobial activities due to the presence of these bioactive compounds [14,15]. Cornus macrophylla belongs to the family Cornaceae, which consists of 55 species. Three species of this family, viz., C. macrophylla, Cornus oblonga, and Cornus capitata, are present in Pakistan [16]. Research carried out during the recent past has shown that plants in genus Cornus are a source of beneficial bioactive compounds. C. macrophylla is a medicinal plant. Its bark can be used orally in powder form or in black tea to treat backache, jaundice, and stomach ulcers [17]. C. macrophylla also exhibited a strong inhibition of aldose reductase, and it may be a potential candidate for the treatment of diabetic retinopathy [18]. In some previous studies, various biological activities such as the antifungal [19], antibacterial [20], and antioxidant [21] activities of numerous compounds and/or complexes isolated from Cornus spp. were investigated. The use of plants that produce antimicrobial compounds is an alternative way to control bacterial attack [8]. By using antimicrobial plants for the protection of crops against pathogens, we can decrease the development of resistance in pathogens caused by synthetic chemical compounds [22]. Aqueous extract of Rhus coriaria showed antibacterial activity and Gas Chromatography Mass Spectrometry (GC/MS) of its aqueous extract showed the presence of 39 compounds. Of these 39 compounds, 2,5-Furandione was documented as having the best antibacterial activity [23]. There are few studies on the isolation of antimicrobial compounds from the genus Cornus. Phytochemical screening of C. macrophylla as a whole plant revealed the presence of alkaloids, steroids, terpenoids, flavonoids, reducing sugars, and tannins. The ethyl acetate, methanolic extracts, and crude extracts showed the presence of alkaloids, terpenoids, tannins, and reducing sugars, while $n$-hexane, chloroform, and ethyl acetate fractions revealed the existence of terpenoids, steroids, flavonoids, tannins, and reducing sugars. The crude and methanolic extracts exhibited antibacterial activity [a $14 \mathrm{~mm}$ inhibition zone diameter (IZD)] at a concentration of $32 \mathrm{mg} / \mathrm{mL}$ [24]. The ethyl acetate extract of C. macrophylla leaves exhibited antibacterial activity against Pseudomonas aeruginosa, a human pathogen. A compound named as kaempferol 3-O- $\alpha$-L-rhamnopyranoside (afzelin) was isolated from C. macrophylla leaves. The minimum inhibitory concentration (MIC) of afzelin was found to be $31 \mu \mathrm{g} / \mathrm{mL}$ against $P$. aeruginosa; however, the antibacterial activity shown by afzelin was less than gentamycin, the reference compound [18]. Compounds isolated from the methanolic extract of the fruit of Cornus mas were $\beta$-hydroxychalcone, 4-acetoxy-5,20,40,60, $\beta$-pentahydroxy-3-methoxychalcone,7,30-dihydroxy-5,40-dimethoxyflavanone, myricetin, quercetin-3-O-rutinoside, gallic acid, ursolic acid, and D-glucose. These compounds exhibited antibacterial activity against Staphylococcus aureus and Pseudomonas aeruginosa [25].

Although there are a few investigations on the isolation of antibacterial compounds against animal pathogens from C. macrophylla around the world, reports on the characterization of antibacterial compounds against plant pathogens are missing. Therefore, the present study would be a useful addition to research work. In the present study, phytochemicals were characterized/identified from C. macrophylla and tested as having antibacterial activities against some plant pathogenic bacterial species, viz., Erwinia carotovora, Ralstonia solanacearum, Xanthomonas axonopodis, and Pseudomonas syringae. Infections due to these bacteria cause serious threats to food security [26].

There are also numerous diseases in plants caused by plant pathogenic bacteria. Plant pathogenic bacteria have a serious effect on crops and reduce the yield of crops [27]. A bacterial disease caused by P. syringae is bacterial blight of wheat, which reduces the yield of wheat every year [28]. Bacterial wilt disease in Solanaceae is caused by R. solanacearum [29], especially in tomato [30]. Similarly, Xylella fastidiosa causes disease in citrus plants [31]. In Rosaceae, fire blight is a disease caused by Erwinia amylovora [32]. E. carotovora is responsible for Cassava bacterial stem rot [33]. Similarly, X. axonopodis is 
responsible for cankers on Citrus maxima [34]. Additionally, Xanthomonas campestris pv. Mangiferae indicae is responsible for mango bacterial canker disease [35]. All of these plant pathogens have a broad host range and cause a number of diseases in many plants. Therefore, the present study was designed to assess the in vitro antibacterial activity of bioactive compounds of $C$. macrophylla separated through methanol, $n$-hexane, chloroform, and ethyl acetate. The metabolites in the most active organic fraction from C. macrophylla were identified with the help of GC/MS and have not been reported in earlier investigations. This study could help to further extend our knowledge of bioactive molecules that can be harnessed as natural eco-friendly antibacterial compounds.

\section{Results and Discussion}

Figure 1 shows the antibacterial activity of C. macrophylla leaf extracts against E. carotovora, $P$. syringae, $R$. solanacearum, and X. axonopodis. In all of these experiments, DMSO kept as a negative control did not show any antibacterial activity while penicillin used as a positive control exhibited the maximum antibacterial activity in terms of IZD.

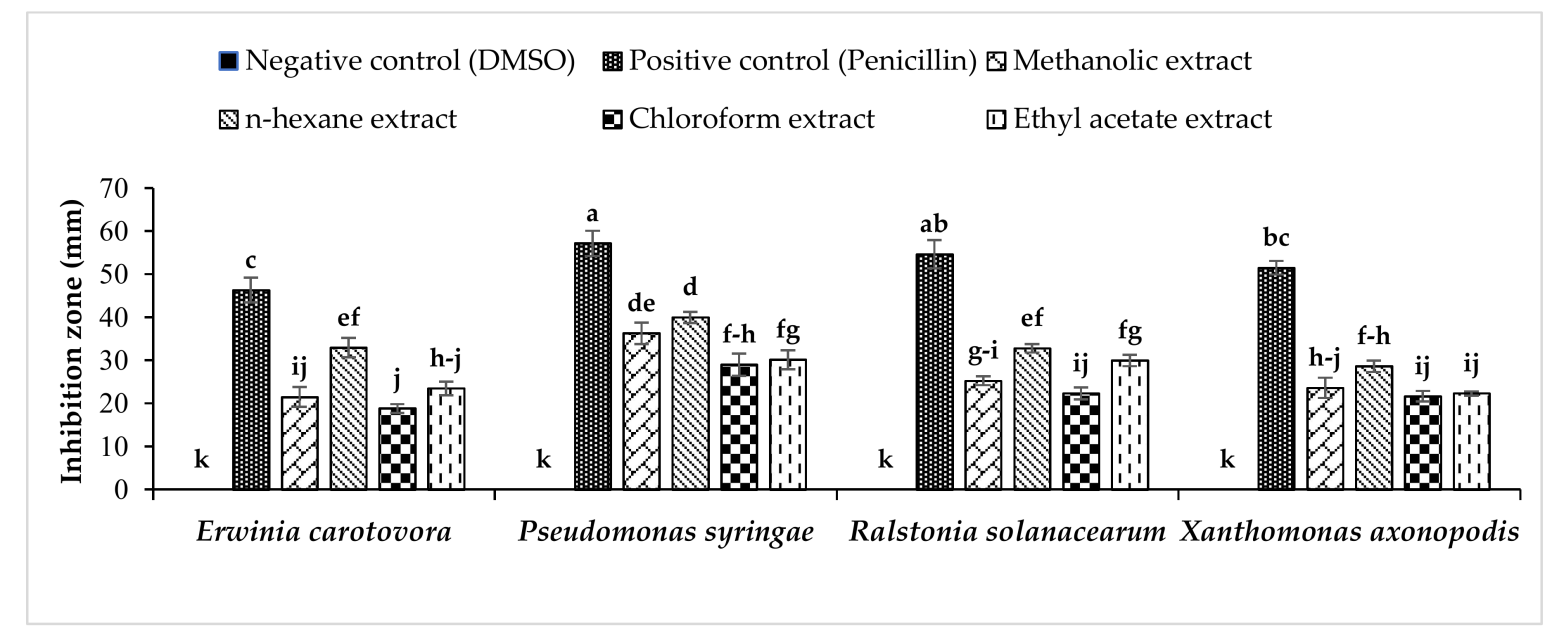

Figure 1. Effect of different organic solvent extracts of Cornus macrophylla leaves on the growth of Erwinia carotovora, Pseudomonas syringae, Ralstonia solanacearum, and Xanthomonas axonopodis. Vertical bars show the standard error of means of three replicates. Values with different letters show a significant difference $(p \leq 0.05)$ as determined by ANOVA followed by Fisher's least significant difference (LSD) Test using Minitab statistical software (Minitab 19).

\subsection{Antibacterial Activity of Methanolic, n-hexane, Chloroform, and Ethyl Acetate Extract of C. macrophylla} Leaves on E. carotovora

Methanolic extract significantly exhibited a $21.5 \mathrm{~mm}$ IZD against E. carotovora while penicillin showed a $46.3 \mathrm{~mm}$ IZD. The $n$-hexane extract revealed the maximum antibacterial activity as compared with methanolic, chloroform, and ethyl acetate extract. The $n$-hexane extract showed a $33 \mathrm{~mm}$ IZD against E. carotovora, whereas extract of chloroform showed an $18.8 \mathrm{~mm}$ IZD, which was less than all other extracts. The ethyl acetate extract also showed substantial results, forming an IZD of $23.5 \mathrm{~mm}$. In the case of organic solvent fractions, a maximum $33 \mathrm{~mm}$ IZD was recorded. In the case of the $n$-hexane extract of C. macrophylla leaves, this IZD was less than the penicillin used as a positive control (Figure 1). These results showed similarities to the findings of [36] in which researchers investigated the effect of Urospermum picroides against E. carotovora and recorded an inhibition zone of 7-8 $\mathrm{mm}$. Inhibition caused by the organic solvent extract of C. macrophylla leaves on E. carotovora was greater than that caused by $U$. picroides. In a previous study, an ethyl acetate fraction of Amaranthus viridis leaf exhibited a $19 \mathrm{~mm}$ IZD against E. carotovora [37]. This higher efficacy can be attributed to a greater amount of antibacterial substances present in the leaves of C. macrophylla. 
2.2. Antibacterial Activity of Methanolic, n-hexane, Chloroform, and Ethyl Acetate Extract of C. macrophylla Leaves on P. syringae

Methanolic extract exhibited a $36.3 \mathrm{~mm}$ IZD against $P$. syringae whereas penicillin showed a $57.2 \mathrm{~mm}$ IZD. The $n$-hexane extract revealed the best antibacterial activity as compared with chloroform and ethyl acetate extract, exhibiting a $40 \mathrm{~mm}$ IZD against $P$. syringae. Extract of chloroform showed a $29 \mathrm{~mm}$ IZD, which was less than all other extracts. Ethyl acetate extract also showed significant results with an IZD of $30.2 \mathrm{~mm}$ (Figure 1). These results showed similarities to the findings of [38] in Polygonum cuspidatum roots against P. syringae and exhibited 100\% inhibition after 24 hours at a $105.11 \mu \mathrm{g} / \mathrm{mL}$ concentration. In another study, an ethyl acetate fraction of $A$. viridis leaf caused a $21 \mathrm{~mm}$ IZD against $P$. syringae [37].

\subsection{Antibacterial Activity of Methanolic, n-hexane, Chloroform, and Ethyl Acetate Extract of C. macrophylla} Leaves on $R$. solanacearum

The antibacterial activity of methanolic extract of C. macrophylla leaves is shown in Figure 1. Methanolic extract exhibited a $25.3 \mathrm{~mm}$ IZD against $R$. solanacearum whereas the corresponding value for penicillin was $54.7 \mathrm{~mm}$. The $n$-hexane extract revealed more potent antibacterial activity than chloroform and ethyl acetate extracts. The $n$-hexane extract showed a $32.8 \mathrm{~mm}$ IZD against $R$. solanacearum. The extract of chloroform showed a $22.3 \mathrm{~mm}$ IZD, which was less than all other extracts. The ethyl acetate extract also showed significant results (a $30 \mathrm{~mm}$ IZD). In this experiment, n-hexane showed maximum antibacterial activity. In an earlier investigation, the methanolic extract of $R$. coriaria exhibited an $18 \mathrm{~mm}$ zone of inhibition against $R$. solanacearum [21]. Ethanolic extract of Ipomoea staphylina has antibacterial activity against Xanthomonas campestris, P. syringae, Klebsiella pneumonia, Escherichia coli, Salmonella typhi, P. aeruginosa and S. aureus. GC/MS analysis of the ethanolic extract revealed the presence of alkaloids, saponins, flavonoids, steroids, glycosides, phenols, and sterols [39].

\subsection{Antibacterial Activity of Methanolic, n-hexane, Chloroform, and Ethyl Acetate Extract of C. macrophylla Leaves on $X$. axonopodis}

Figure 1 shows the data on the antibacterial activity of C. macrophylla extracts against X. axonopodis. Methanolic extract exhibited a $23.7 \mathrm{~mm}$ IZD against $X$. axonopodis whereas penicillin showed a $51.5 \mathrm{~mm}$ IZD. The $n$-hexane extract revealed substantial antibacterial activity as compared with methanol, chloroform, and ethyl acetate extract. The $n$-hexane extract showed a $28.7 \mathrm{~mm}$ IZD against X. axonopodis. On the other hand, the extract of chloroform showed a minimum (21.7 mm IZD) bactericidal activity. The ethyl acetate extract also showed significant results (a $22.3 \mathrm{~mm}$ IZD). A maximum IZD of $28.7 \mathrm{~mm}$ was recorded in the case of $n$-hexane extract, which was less than that of penicillin. These results are in agreement with the findings of [40] where Amaranthus tricolor showed $24 \%-62 \%$ antibacterial activity against $X$. axonopodis.

\subsection{Gas Chromatography Mass Spectrometry (GC/MS) Analysis}

In total, 55 compounds were identified in the $n$-hexane fraction of $C$. macrophylla. The retention time (RT), peak areas of component (\%), molecular weight, and their molecular formulas are presented in Table 1. Of these compounds, only three compounds revealed $>5 \%$ peak areas, viz., $\alpha$-amyrin; A'-Neogammacer-22(29)-en-3-ol, acetate, (3.beta.,21.beta.)-; and $\beta$-amyrin (Figure 2A-C). The antibacterial activity of $\alpha$-amyrin and $\beta$-amyrin was also reported against $S$. aureus, Bacillus subtilis, Enterococcus faecium and Staphylococcus saprophyticus $[41,42]$. Both $\alpha$ - and $\beta$-amyrin triterpenes have also been isolated from Dorstenia arifolia and documented as having antimicrobial activities [43]. The compounds $\alpha-, \beta$-amyrin, and $\alpha$-amyrin phenylacetate reduced the bacterial viability to less than $20 \%$ [44]. S. aureus (MRSA) is an important human pathogen that has become resistant to antibiotics. The compound $\alpha$-amyrin has been reported to exhibit antimicrobial activities against $S$. aureus. The compound $\alpha$-amyrin regulates multiple desirable targets in cell division, the two-component 
system, ABC transporters, fatty acid biosynthesis, peptidoglycan biosynthesis, aminoacyl-tRNA synthetase, and ribosome and b-lactam resistance pathways [45], resulting in the destabilization of the bacterial cell membrane, a halt in protein synthesis, and inhibition of cell growth that eventually lead to cell death [46]. Furthermore, it causes disorganizing effects on cardiolipin-rich domains present in the membrane of E. coli [47]. The $\alpha$-amyrin identified from Pyrus bretschneideri Rehd. also exhibited antibacterial activity [48]. Moreover, $\alpha$ - and $\beta$-amyrin esters are also documented as antibacterial compounds [49]. In another investigation, $\beta$-amyrin isolated from leaves of Siraitia grosvenorii showed antibacterial activity against Streptococcus mutans, Actinobacillus actinomycetemcomitans, and Fusobacterium nucleatum with minimum inhibitory concentrations of $48.80,>100$, and $48.80 \mu \mathrm{g} \mathrm{mL}^{-1}$, respectively [50]. On the other hand, there are no previous reports that describe the antibacterial activity of A'-Neogammacer-22(29)-en-3-ol, acetate. In the present study, a higher level antibacterial activity of the $n$-hexane extract of $C$. macrophylla leaves was recorded as compared with chloroform and ethyl acetate extracts; $n$-hexane is a non-polar solvent and has a greater ability to extract more lipophilic compounds like $\alpha$-amyrin, as compared with chloroform and ethyl acetate. Since GC/MS of $n$-hexane extract of $C$. macrophylla leaves from Pakistan has shown the presence of $\alpha$-amyrin having the highest peak area, more studies are required to isolate and characterize its bioactive constituents.

Table 1. Compounds Identified in Gas Chromatography Mass Spectrometry Analysis.

\begin{tabular}{|c|c|c|c|c|c|c|}
\hline $\begin{array}{l}\text { Sr. } \\
\#\end{array}$ & $\begin{array}{l}\text { Retention } \\
\text { Time (min.) }\end{array}$ & Name of Compound & $\begin{array}{l}\text { Molecular } \\
\text { Formula }\end{array}$ & $\begin{array}{l}\text { Molecular } \\
\text { Weight }\end{array}$ & $\begin{array}{l}\text { Peak } \\
\text { Area } \%\end{array}$ & $\begin{array}{l}\text { Class of } \\
\text { Compound }\end{array}$ \\
\hline 1 & 4.255 & 3-Hexanone & $\mathrm{C}_{6} \mathrm{H}_{12} \mathrm{O}$ & 100 & 0.01 & $\begin{array}{l}\text { Di alkyl } \\
\text { Ketone }\end{array}$ \\
\hline 2 & 4.389 & 2-Hexanone & $\mathrm{C}_{6} \mathrm{H}_{12} \mathrm{O}$ & 100 & 0.01 & Ketone \\
\hline 3 & 22.776 & 2,4-Di-tert-butylphenol & $\mathrm{C}_{14} \mathrm{H}_{22} \mathrm{O}$ & 206 & 0.01 & Phenol \\
\hline 4 & 24.436 & Nonadecane & $\mathrm{C}_{19} \mathrm{H}_{40}$ & 268 & 0.02 & $\begin{array}{l}\text { Aliphatic } \\
\text { Alkane }\end{array}$ \\
\hline 5 & 26.146 & Heptadecane & $\mathrm{C}_{17} \mathrm{H}_{36}$ & 240 & 0.02 & $\begin{array}{l}\text { Aliphatic } \\
\text { Alkane }\end{array}$ \\
\hline 6 & 27.771 & Heneicosane & $\mathrm{C}_{21} \mathrm{H}_{44}$ & 296 & 0.03 & $\begin{array}{l}\text { Aliphatic } \\
\text { Alkane }\end{array}$ \\
\hline 7 & 28.339 & Neophytadiene & $\mathrm{C}_{20} \mathrm{H}_{38}$ & 278 & 0.56 & Terpene \\
\hline 8 & 28.419 & 2-Pentadecanone, 6,10,14-trimethyl- & $\mathrm{C}_{18} \mathrm{H}_{36} \mathrm{O}$ & 268 & 0.03 & Terpenoid \\
\hline 9 & 29.682 & Hexadecanoic acid, methyl ester & $\mathrm{C}_{17} \mathrm{H}_{34} \mathrm{O}_{2}$ & 270 & 0.11 & $\begin{array}{l}\text { Saturated } \\
\text { Fatty acid }\end{array}$ \\
\hline 10 & 30.678 & Hexadecanoic acid, ethyl ester & $\mathrm{C}_{18} \mathrm{H}_{36} \mathrm{O}_{2}$ & 284 & 0.04 & $\begin{array}{l}\text { Saturated } \\
\text { Fatty acid }\end{array}$ \\
\hline 11 & 32.098 & $\begin{array}{l}\text { 9,12-Octadecadienoic acid }(Z, Z)-\text {, methyl } \\
\text { ester }\end{array}$ & $\mathrm{C}_{19} \mathrm{H}_{34} \mathrm{O}_{2}$ & 294 & 0.06 & $\begin{array}{l}\text { Unsaturated } \\
\text { fatty acid }\end{array}$ \\
\hline 12 & 32.183 & $\begin{array}{l}\text { 9,12,15-Octadecatrienoic acid, methyl } \\
\text { ester, }(Z, Z, Z)-\end{array}$ & $\mathrm{C}_{19} \mathrm{H}_{32} \mathrm{O}_{2}$ & 292 & 0.26 & $\begin{array}{l}\text { Unsaturated } \\
\text { fatty acid }\end{array}$ \\
\hline 13 & 32.556 & Methyl stearate & $\mathrm{C}_{19} \mathrm{H}_{38} \mathrm{O}_{2}$ & 298 & 0.02 & Fatty acid \\
\hline 14 & 32.824 & 9,12-Octadecadienoic acid $(Z, Z)-$ & $\mathrm{C}_{18} \mathrm{H}_{32} \mathrm{O}_{2}$ & 280 & 1.09 & $\begin{array}{l}\text { Unsaturated } \\
\text { fatty acid }\end{array}$ \\
\hline 15 & 33.005 & Linoleic acid ethyl ester & $\mathrm{C}_{20} \mathrm{H}_{36} \mathrm{O}_{2}$ & 308 & 0.17 & $\begin{array}{l}\text { Unsaturated } \\
\text { fatty acid }\end{array}$ \\
\hline 16 & 33.092 & $\begin{array}{c}\text { 9,12,15-Octadecatrienoic acid, ethyl ester, } \\
(Z, Z, Z)-\end{array}$ & $\mathrm{C}_{20} \mathrm{H}_{34} \mathrm{O}_{2}$ & 306 & 0.31 & Fatty acid \\
\hline 17 & 33.175 & $\begin{array}{l}\text { 2,2-Dimethyl-6-methylene-1-[3,5- } \\
\text { dihydroxy-1-pentenyl]cyclohexan- }\end{array}$ & $\mathrm{C}_{14} \mathrm{H}_{24} \mathrm{O}_{4}$ & 256 & 0.08 & Phenolic \\
\hline 18 & 33.708 & Phytol, acetate & $\mathrm{C}_{22} \mathrm{H}_{42} \mathrm{O}_{2}$ & 338 & 0.06 & Terpene \\
\hline 19 & 34.360 & $\begin{array}{l}\text { Ergost-25-ene-3,6-dione, } \\
\text { 5,12-dihydroxy-, (5. «alpha.,12.beta.)- }\end{array}$ & $\mathrm{C}_{28} \mathrm{H}_{44} \mathrm{O}_{4}$ & 444 & 0.15 & Ester \\
\hline 20 & 34.824 & Eicosane & $\mathrm{C}_{20} \mathrm{H}_{42}$ & 282 & 0.09 & $\begin{array}{l}\text { Aliphatic } \\
\text { Alkane }\end{array}$ \\
\hline 21 & 35.457 & $\begin{array}{l}\text { 2,5-Bis(1,1-dimethylbutyl)-4- } \\
\text { methoxyphenol }\end{array}$ & $\mathrm{C}_{19} \mathrm{H}_{32} \mathrm{O}_{2}$ & 292 & 0.28 & Phenolic \\
\hline 22 & 35.546 & Urs-12-ene & $\mathrm{C}_{30} \mathrm{H}_{50}$ & 410 & 0.17 & Tri-Terpenoid \\
\hline
\end{tabular}


Table 1. Cont.

\begin{tabular}{|c|c|c|c|c|c|c|}
\hline $\begin{array}{l}\text { Sr. } \\
\#\end{array}$ & $\begin{array}{l}\text { Retention } \\
\text { Time (min.) }\end{array}$ & Name of Compound & $\begin{array}{l}\text { Molecular } \\
\text { Formula }\end{array}$ & $\begin{array}{l}\text { Molecular } \\
\text { Weight }\end{array}$ & $\begin{array}{l}\text { Peak } \\
\text { Area } \%\end{array}$ & $\begin{array}{l}\text { Class of } \\
\text { Compound }\end{array}$ \\
\hline 23 & 35.721 & $\begin{array}{c}\text { 4,4,6a,6b,8a,11,11,14b-Octamethyl- } \\
\text { 1,4,4a,5,6,6a,6b,7,8,8a,9,10,11,12,12a,14, } \\
\text { 14a,14b-octadecahydro-2H-picen-3-one }\end{array}$ & $\mathrm{C}_{30} \mathrm{H}_{48} \mathrm{O}$ & 424 & 0.32 & Tri-Terpenoid \\
\hline 24 & 36.080 & 2-Methyltetracosane & $\mathrm{C}_{25} \mathrm{H}_{52}$ & 352 & 0.03 & Tri-Terpenoid \\
\hline 25 & 37.098 & $\begin{array}{c}\text { Spiro[androst-5-ene-17,1'-cyclobutan]-2'- } \\
\text { one, 3-hydroxy-, (3. }\end{array}$ & $\mathrm{C}_{22} \mathrm{H}_{32} \mathrm{O}_{2}$ & 328 & 0.02 & Steroid \\
\hline 26 & 37.274 & Tetracosane & $\mathrm{C}_{24} \mathrm{H}_{50}$ & 338 & 0.04 & Alkane \\
\hline 27 & 37.810 & 22,23-Dibromostigmasterol acetate & $\mathrm{C}_{31} \mathrm{H}_{50} \mathrm{Br}_{2} \mathrm{O}_{2}$ & 612 & 0.50 & Steroid Ester \\
\hline 28 & 37.880 & Urs-12-ene-3.beta.,11.beta.-diol, diacetate & $\mathrm{C}_{34} \mathrm{H}_{54} \mathrm{O}_{4}$ & 526 & 0.69 & Tri-Terpenoid \\
\hline 29 & 37.955 & 13,27-Cyclours-11-en-3-ol, acetate & $\mathrm{C}_{32} \mathrm{H}_{50} \mathrm{O}_{2}$ & 466 & 0.89 & Ester \\
\hline 30 & 38.280 & Ether, dodecyl isopropyl & $\mathrm{C}_{15} \mathrm{H}_{32} \mathrm{O}$ & 228 & 0.01 & Ether \\
\hline 31 & 38.350 & Undec-10-ynoic acid, decyl ester & $\mathrm{C}_{21} \mathrm{H}_{38} \mathrm{O}_{2}$ & 322 & 0.02 & Ester \\
\hline 32 & 38.416 & Dotriacontane, 1 -iodo- & $\mathrm{C}_{32} \mathrm{H}_{65} \mathrm{I}$ & 576 & 0.01 & Alkane \\
\hline 33 & 38.552 & $\begin{array}{l}\text { 9,19-Cyclolanost-24-ene-3,26-diol, } \\
\text { diacetate }\end{array}$ & $\mathrm{C}_{34} \mathrm{H}_{54} \mathrm{O}_{4}$ & 526 & 0.17 & Diester \\
\hline 34 & 38.810 & 3,7,11,15-Tetramethyl-2-hexadecen-1-ol & $\mathrm{C}_{20} \mathrm{H}_{40} \mathrm{O}$ & 296 & 0.13 & Alkane \\
\hline 35 & 38.884 & 13,14-Epoxyursan-3-ol, acetate & $\mathrm{C}_{31} \mathrm{H}_{50} \mathrm{O}_{3}$ & 470 & 0.12 & Ester \\
\hline 36 & 39.204 & Olean-12-en-3-ol, acetate, (3.beta.)- & $\mathrm{C}_{32} \mathrm{H}_{52} \mathrm{O}_{2}$ & 468 & 3.10 & Ester \\
\hline 37 & 39.307 & $\beta$-amyrin & $\mathrm{C}_{30} \mathrm{H}_{50} \mathrm{O}$ & 426 & 6.77 & Ester \\
\hline 38 & 39.407 & ß.-Amyrone & $\mathrm{C}_{30} \mathrm{H}_{48} \mathrm{O}$ & 424 & 1.21 & Ester \\
\hline 39 & 39.848 & Lup-20(29)-en-3-one & $\mathrm{C}_{30} \mathrm{H}_{48} \mathrm{O}$ & 424 & 1.17 & Tri-Terpenoid \\
\hline 40 & 40.012 & $\begin{array}{l}\text { 1,4-Benzenedicarboxylic acid, } \\
\text { bis(2-ethylhexyl) ester }\end{array}$ & $\mathrm{C}_{24} \mathrm{H}_{38} \mathrm{O}_{4}$ & 390 & 0.11 & $\begin{array}{l}\text { Benzene } \\
\text { Carboxylic } \\
\text { Acid }\end{array}$ \\
\hline 41 & 40.380 & Squalene & $\mathrm{C}_{30} \mathrm{H}_{50}$ & 410 & 0.93 & Tri-Terpenoid \\
\hline 42 & 40.923 & $\alpha$-amyrin & $\mathrm{C}_{30} \mathrm{H}_{50} \mathrm{O}$ & 426 & 32.64 & Tri-Terpenoid \\
\hline 43 & 41.621 & Tetracontane & $\mathrm{C}_{40} \mathrm{H}_{82}$ & 562 & 2.57 & Alkane \\
\hline 44 & 42.133 & Thunbergol & $\mathrm{C}_{20} \mathrm{H}_{34} \mathrm{O}$ & 290 & 2.65 & Steroid \\
\hline 45 & 42.426 & $\begin{array}{l}\text { Cholest-5-en-3-ol (3.beta.)-, } \\
\text { carbonochloridate }\end{array}$ & $\mathrm{C}_{28} \mathrm{H}_{45} \mathrm{ClO}_{2}$ & 448 & 2.63 & Steroid \\
\hline 46 & 42.750 & Octacosyl acetate & $\mathrm{C}_{30} \mathrm{H}_{60} \mathrm{O}_{2}$ & 452 & 2.18 & Fatty Alcohol \\
\hline 47 & 43.300 & $\begin{array}{l}\mathrm{A}^{\prime} \text {-Neogammacer-22(29)-en-3-ol, } \\
\text { acetate, (3.beta.,21.beta.)- }\end{array}$ & $\mathrm{C}_{32} \mathrm{H}_{52} \mathrm{O}_{2}$ & 468 & 25.97 & Ester \\
\hline 48 & 43.735 & Hexatriacontane & $\mathrm{C}_{36} \mathrm{H}_{74}$ & 506 & 2.12 & $\begin{array}{l}\text { Aliphatic } \\
\text { Alkane }\end{array}$ \\
\hline 49 & 43.909 & Stigmast-5-en-3-ol, oleate & $\mathrm{C}_{47} \mathrm{H}_{82} \mathrm{O}_{2}$ & 678 & 2.15 & Ester \\
\hline 50 & 44.306 & Acetyl betulinaldehyde & $\mathrm{C}_{32} \mathrm{H}_{50} \mathrm{O}_{3}$ & 482 & 3.68 & Tri-Terpenoid \\
\hline 51 & 44.600 & Silane, chlorodiethyl(dodec-9-ynyloxy)- & $\mathrm{C}_{16} \mathrm{H}_{31} \mathrm{ClOSi}$ & 302 & 0.79 & Alkane \\
\hline 52 & 44.990 & Lanosta-8,24-dien-3-ol, acetate, (3.beta.)- & $\mathrm{C}_{32} \mathrm{H}_{52} \mathrm{O}_{2}$ & 468 & 1.69 & Ester \\
\hline 53 & 46.150 & Pentadecanophenone & $\mathrm{C}_{21} \mathrm{H}_{34} \mathrm{O}$ & 302 & 0.27 & Ketone \\
\hline 54 & 46.404 & $\begin{array}{l}\text { Acetic acid, 4,4,6a,6b,8a,11,12,14b- } \\
\text { octamethyl-14-oxo-1,2,3,4,4a, }\end{array}$ & $\mathrm{C}_{32} \mathrm{H}_{50} \mathrm{O}_{3}$ & 482 & 0.54 & $\begin{array}{l}\text { Carboxylic } \\
\text { acid }\end{array}$ \\
\hline 55 & 46.783 & Ergosta-5,22-dien-3-ol, (3.beta.,22E)- & $\mathrm{C}_{28} \mathrm{H}_{46} \mathrm{O}$ & 398 & $\begin{array}{c}0.30 \\
\text { Total } \\
100 \%\end{array}$ & Cholesterol \\
\hline
\end{tabular}

Note: Compounds highlighted in bold were detected as having higher peak area percentages $(>5 \%)$.

A

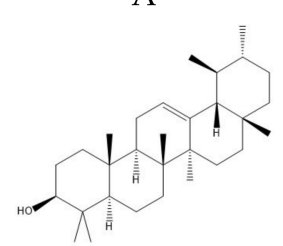

B

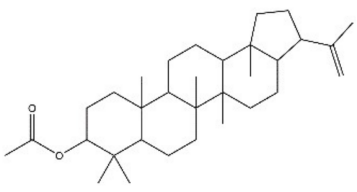

C

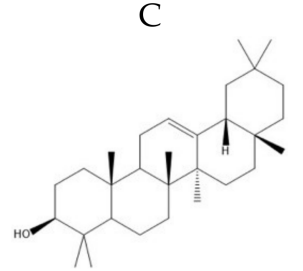

Figure 2. (A-C). Chemical structures of (A) $\alpha$-amyrin, (B) A'-Neogammacer-22(29)-en-3-ol, acetate, (3.beta.,21.beta.)-, and (C) $\beta$-amyrin. 


\section{Materials and Methods}

\subsection{Collection and Identification of Plant Material}

Fresh leaves of C. macrophylla were collected from the Bara Gali summer campus, University of Peshawar, Khyber Pakhtunkhwa (KPK), Galyat, Pakistan. The voucher specimen (UOG-000585) was deposited in the herbarium of the Department of Botany, University of Gujrat, Gujrat, Pakistan.

\subsection{Preparation of C. macrophylla Leaves Extracts}

After collection, leaves of $C$. macrophylla were sun dried for 1 week and dried leaves $(1 \mathrm{~kg})$ were ground with the help of a pestle and mortar to make a fine powder. The powder (400 g) was soaked in 1-L of methanol in a glass jar and incubated for 1 week at room temperature $\left(25^{\circ} \mathrm{C}\right)$ and frequently stirred with a glass rod. The filtration of the extract was performed by using four layered muslin cloth followed by a final filtration with Whatman filter paper No. 1 . The filtrate was evaporated at $45^{\circ} \mathrm{C}$ by using a rotary evaporator (Model: Laborata 4000/Gl, Heidolph, Schwabach, Germany). Extra methanol from this extract was evaporated under currents of clean air at room temperature to yield a viscous fluid termed as methanolic extract. This methanolic extract was reconstituted in double-distilled water $(200 \mathrm{~mL})$ and fractionated with three organic solvents, viz., $n$-hexane, chloroform, and ethyl acetate, first with $200 \mathrm{~mL}$ of $n$-hexane in a $500 \mathrm{~mL}$ separating funnel. This setup was left overnight until the $n$-hexane formed a layer in the upper portion of the separating funnel, which was then separated into a glass beaker. The process was repeated thrice by adding fresh solvent into the aqueous solution. A similar process was used for the extraction with chloroform and ethyl acetate. The organic solvent extracts thus obtained were evaporated by using a rotary evaporator, as discussed earlier, and stored at $4{ }^{\circ} \mathrm{C}$ until further use.

\subsection{Culturing of Target Plant Pathogenic Bacterial Species}

Plant pathogenic bacterial cultures were obtained from the Culture Bank of Pakistan, University of the Punjab, Lahore, Pakistan. The bacterial cultures with their accession numbers were E. carotovora (FCBP-PB-0421), P. syringae (FCBP-PB-0405), R. solanacearum (FCBP-PB-0407), and X. axonopodis (FCBP-PB-001). These cultures were sub-cultured on a Lysogeny broth (LB) medium in $9 \mathrm{~cm}$ diameter glass petri plates until colonies became visible and stored in a refrigerator at $4{ }^{\circ} \mathrm{C}$ for further use.

\subsection{Preparation of Control and Stock Solutions, Culture Medium, and Antibacterial Assays}

For antibacterial assays, a disk diffusion method was adopted according to the procedure described in our previous publication, with slight modifications [51]. For the preparation of the negative control solution, $166 \mu \mathrm{L}$ of DMSO was mixed with $333 \mu \mathrm{L}$ of autoclaved distilled water to make a final volume of $500 \mu \mathrm{L}$ and for the preparation of the positive control solution, $50 \mathrm{mg}$ of penicillin was dissolved in $166 \mu \mathrm{L}$ DMSO and $333 \mu \mathrm{L}$ of autoclaved distilled water was added to make a volume of $500 \mu \mathrm{L}$. Stock solutions of organic solvent extracts were prepared in a way similar to the preparation of the positive control solution. $50 \mathrm{mg}$ of leaves extract in each organic solvent viz. methanol, $n$-hexane, chloroform and ethyl acetate were dissolved into $166 \mu \mathrm{L}$ of DMSO and then added $333 \mu \mathrm{L}$ of autoclaved distilled water to make volume up to $500 \mu \mathrm{L}$. In this way, the positive control, penicillin, and all organic solvent extracts of $C$. macrophylla leaves were tested for their antibacterial efficacy at a $100 \mathrm{mg} \mathrm{mL}^{-1}$ concentration. The LB medium was used for inoculation of bacterial species. For the preparation of the LB medium, $1000 \mathrm{~mL}$ of distilled water was added into the conical flask, then $5 \mathrm{~g}$ of yeast extract, $10 \mathrm{~g}$ of tryptone, $10 \mathrm{~g}$ of $\mathrm{NaCl}$, and $15 \mathrm{~g}$ of agar powder were added and mixed well to dissolve all the nutrients. Afterwards, the flask opening was covered with aluminum foil and sterilized in autoclave for $20 \mathrm{~min}$ at $121^{\circ} \mathrm{C}$. After preparing the LB agar plates, bacterial inocula @ $1 \times 10^{5} \mathrm{cfu} / \mathrm{mL}$ were spread evenly onto these plates and, after spreading, filter paper discs $(6 \mathrm{~mm})$ were placed on these plates. Leaf extract $(25 \mu \mathrm{L})$ for each solvent (methanol, $n$-hexane, chloroform, and ethyl acetate) was added onto these filter paper discs contained in Petriplates and incubated at $37^{\circ} \mathrm{C}$. Antibacterial activity was 
measured after $72 \mathrm{~h}$ in terms of inhibition zone diameter (IZD) with the help of a measuring scale [37]. All chemicals used were of Merck KGaA, Darmstadt, Germany.

\subsection{Gas Chromatography Mass Spectrometry (GC/MS)}

Constituents of $n$-hexane extract of C. macrophylla leaves showing higher bioactivity were analyzed by using GC/MS on a Clarus 500 Mass Spectrometer (PerkinElmer, Waltham, Massachusetts, USA) whose detectable mass range was set at 35-500 m/z. The ion source and interface temperatures were $200{ }^{\circ} \mathrm{C}$ and $250{ }^{\circ} \mathrm{C}$, respectively. The start and end times were $2.50 \mathrm{~min}$ and $47.14 \mathrm{~min}$, respectively. The column oven temp. was $40^{\circ} \mathrm{C}$ whereas the injection temp. was $25^{\circ} \mathrm{C}$. Injection mode was split and flow control mode was set at a pressure of $100 \mathrm{kPa}$. Total flow was $13.9 \mathrm{~mL} / \mathrm{min}$ while column flow was $1.78 \mathrm{~mL} / \mathrm{min}$ with a linear velocity of $48.1 \mathrm{~cm} / \mathrm{sec}$. Purge flow was kept at $3.0 \mathrm{~mL} / \mathrm{min}$ and a split ratio of 5.1. The oven temperature was programmed first at $40{ }^{\circ} \mathrm{C}$ for 5 min with an increase of $5{ }^{\circ} \mathrm{C} \mathrm{min}$ mi $^{-1}$ to $80{ }^{\circ} \mathrm{C}$, then $5{ }^{\circ} \mathrm{C} \mathrm{min}^{-1}$ to $300{ }^{\circ} \mathrm{C}$ for $5 \mathrm{~min}$. The mass spectral library consulted for GC/MS analysis for the identification of components in our study was NIST14.lib. This part of the research was conducted at the Thermal Energy Research Lab., National University of Sciences and Technology, Islamabad, Pakistan.

\subsection{Statistical Design and Analysis}

The experiment was performed by adopting Completely Randomized Design (CRD). For statistical analysis, ANOVA was done followed by Fisher's least significant difference (LSD) Test using Minitab Statistical Software (Minitab 19, State College, Pennsylvania, USA).

\section{Conclusions}

The present study revealed the antibacterial efficacy of C. macrophylla leaf extracts. GC/MS analysis of $n$-hexane extract depicted the presence of $\alpha$-amyrin having the highest peak area $\%$ age. It may be concluded that this compound, having the highest peak area \% age, was responsible for the antibacterial activity recorded in the present study. The structure of this compound can be utilized further to develop eco-friendly bactericides in the future.

Author Contributions: Conceptualization, T.K. and M.S.I.; Formal analysis, H.M.W. and F.I.J.; Methodology, U.A., A.A., Z.A., and N.A.; Resources, R.N. and S.A.C.; Software, H.M.W. and F.I.J.; Supervision, M.A.; Validation, A.N.; Writing - original draft, T.K. and M.S.I. All authors have read and agreed to the published version of the manuscript.

Funding: This research received no external funding.

Conflicts of Interest: The authors declare no conflicts of interest.

\section{References}

1. Balouiri, M.; Sadiki, M.; Ibnsouda, S.K. Methods for in vitro evaluating antimicrobial activity: A review. J. Pharm. Biomed. Anal. 2016, 6, 71-79. [CrossRef] [PubMed]

2. Tayel, A.A.; Shaban, S.M.; Moussa, S.H.; Elguindy, N.M.; Diab, A.M.; Mazrou, K.E.; El-Sabbagh, S.M. Bioactivity and application of plant seeds' extracts to fight resistant strains of Staphylococcus aureus. Ann. Agric. Crop. Sci. 2018, 63, 47-53. [CrossRef]

3. Mekonnen, A.; Yitayew, B.; Tesema, A.; Taddese, S. In vitro antimicrobial activity of essential oil of Thymus schimperi, Matricaria chamomilla, Eucalyptus globulus, and Rosmarinus officinalis. Int. J. Microbiol. 2016. [CrossRef] [PubMed]

4. Mahmood, I.; Imadi, S.R.; Shazadi, K.; Gul, A.; Hakeem, K.R. Effects of Pesticides on Environment. In Plant, Soil and Microbes: Vol. 1 Implications in Crop Science; Hakeem, K.R., Akhtar, M.S., Akmar Abdullah, S.N., Eds.; Springer International Publishing: Cham, Switzerland, 2016; pp. 253-269.

5. Donga, T.K.; Eklo, O.M. Environmental load of pesticides used in conventional sugarcane production in Malawi. Crop prot. 2018, 108, 71-77. [CrossRef] 
6. Cruz Paredes, C.; Balbás, P.B.; Gomez-Velasco, A.; Juarez, Z.N.; Arreola, E.S.; Hernández, L.R.; Bach, H. Antimicrobial, antiparasitic, anti-inflammatory, and cytotoxic activities of Lopezia racemosa. J. World Sci. 2013, 2013. [CrossRef]

7. Kumari, S.; Sharma, H.R. Farmers' perception on environmental effects of pesticide use, climate change and strategies used in mountain of Western Himalaya. Int. J. Agric. 2018, 8, 57-68.

8. Köhl, J.; Kolnaar, R.; Ravensberg, W.J. Mode of action of microbial biological control agents against plant diseases: relevance beyond efficacy. Front. Plant Sci. 2019, 10, 845. [CrossRef]

9. Shah, S.; Shah, S.M.M.; Ahmad, Z.; Yaseen, M.; Shah, R.; Sadiq, A.; Khan, B. Phytochemicals, in vitro antioxidant, total phenolic contents and phytotoxic activity of Cornus macrophylla Wall bark collected from the North-West of Pakistan. Pak. J. Pharm. Sci. 2015, 28, 23-28.

10. Lamichhane, J.R.; Dachbrodt-Saaydeh, S.; Kudsk, P.; Messéan, A. Toward a reduced reliance on conventional pesticides in European agriculture. Plant Dis. 2016, 100, 10-24. [CrossRef]

11. Mahizan, N.A.; Yang, S.K.; Moo, C.L.; Song, A.A.; Chong, C.M.; Chong, C.W.; Lai, K.S. Terpene derivatives as a potential agent against antimicrobial resistance (AMR) pathogens. Molecules 2019, 24, 2631. [CrossRef]

12. Sasidharan, S.; Chen, Y.; Saravanan, D.; Sundram, K.M.; Latha, L.Y. Extraction, isolation and characterization of bioactive compounds from plants' extracts. Afr. J. Tradit. Complement. Altern. Med 8, 1-10. [CrossRef]

13. Ghorbanpour, M.; Omidvari, M.; Abbaszadeh-Dahaji, P.; Omidvar, R.; Kariman, K. Mechanisms underlying the protective effects of beneficial fungi against plant diseases. Biol. Control. 2018, 117, 147-157. [CrossRef]

14. Cimanga, K.R.; Bool-Miting, F.M.; Lutete, G.T.; Kabangu, O.K.; Vlietinck, A.J.; Pieters, L. Antibacterial screening of aqueous extracts of some medicinal plant and their fractions used as antidiarrheal agents in Kinshasa-Democratic Republic of Congo. Int. J. Pharm. Pharm. Sci. 2018, 7, 223-242.

15. Louis, H.; Linus, M.N.; Israt, A.; Innocent, J.; Amos, P.I.; Magu, T.O. Antimicrobial activity of stem, leave and root plant extract of Sclerocarya birrea and Sterculia setigera against some selected microorganisms. World. Sci. News 2018, 92, 309-326.

16. Saira, H.; Iqbal, M. Conservation status of Cornus macrophylla: An important medicinal plant from Himalaya. J. Biodivers. Endanger. Species 2017, 5. [CrossRef]

17. Khan, W.M.; Shah, S.Z.; Khan, M.S.; Akhtar, N. Evaluation of indigenous knowledge of medicinal plants from Tall Dardyal Hills, Khyber Pakhtunkhwa, Pakistan. J. Herb. Med. 2019. [CrossRef]

18. Kim, H.Y.; Oh, J.H. Screening of Korean forest plants for rat lens aldose reductase inhibition. Biosci. Biotechnol. Biochem. 1999, 63, 184-188. [CrossRef]

19. Bayan, Y.; Yilar, M.; Onaran, A. Evaluation of Antifungal Activity of Methanol Plant Extracts from Cornus mas L. and Morus alba L. In Proceedings of the Sixth International Scientific Agricultural Symposium "Agrosym 2015", Book of Proceedings, University of East Sarajevo. Jahorina, Bosnia and Herzegovina, 15-18 October 2015; pp. 640-643.

20. Lee, S.; So, Y.J.; Shin, M.; Cho, J.; Lee, J. Antibacterial effects of afzelin isolated from Cornus macrophylla on Pseudomonas aeruginosa, a leading cause of illness in immunocompromised individuals. Molecules 2014, 19, 3173-3180. [CrossRef]

21. Moldovan, B.; Filip, A.; Clichici, S.; Suharoschi, R.; Bolfa, P.; David, L. Antioxidant activity of Cornelian cherry (Cornus mas L.) fruits extract and the in vivo evaluation of its anti-inflammatory effects. J. Funct. Foods. 2016, 26, 77-87. [CrossRef]

22. Khameneh, B.; Iranshahy, M.; Soheili, V.; Bazzaz, B.S.F. Review on plant antimicrobials: A mechanistic viewpoint. Antimicrob. Resist. Infect. Control. 2019, 8, 118. [CrossRef]

23. Rashid, T.S.; Sijam, K.; Kadir, J.; Saud, H.M.; Awla, H.K.; Zulperi, D.; Hata, E.M. Screening for active compounds in Rhus coriaria L. crude extract that inhibit the growth of Pseudomonas syringae and Ralstonia solanacearum. Indian J. Agr. Res. 2016, 50, 15-21.

24. Uddin, G.; Waliullah, R.A.; Siddiqui, B.S.; Rehman, T.U.; Ali, M.; Azam, S.; Qaisar, M. Phytochemical screening and antimicrobial activity of Cornus macrophylla Wall. ex Roxb. Middle East J. Sci. Res. 2011, 9, 516-519.

25. Rudrapaul, P.; Kyriakopoulos, A.M.; De, U.C.; Zoumpourlis, V.; Dinda, B. New flavonoids from the fruits of Cornus mas, Cornaceae. Phytochem. Lett. 2015, 11, 292-295. [CrossRef]

26. Figueroa, M.; Hammond-Kosack, K.E.; Solomon, P.S. A review of wheat diseases-a field perspective. Mol. Plant Pathol. 2018, 19, 1523-1536. [CrossRef] [PubMed]

27. Mulaw, T.; Wamishe, Y.; Jia, Y. Characterization and in plant detection of bacteria that cause bacterial panicle blight of rice. American J. Plant Sci. 2018, 9, 667. [CrossRef] 
28. Shaabani, B.; Rezaei, R.; Charehgani, H.; Salehi, A. Study on Antibacterial Effect of Some Essential Oil on Bacterial Blight of Wheat Caused by Pseudomonas syringae pv. syringae under in vitro Conditions. Proceedings of $22^{\text {nd }}$ Iranian Plant Protection Congress, College of Agriculture and Natural Resources, University of Tehran, Karaj, Iran, 27-30 August 2016; 2016; p. 365.

29. Nakaho, K.; Seo, S.; Ookawa, K.; Inoue, Y.; Ando, S.; Kanayama, Y.; Takahashi, H. Involvement of a vascular hypersensitive response in quantitative resistance to Ralstonia solanacearum on tomato rootstock cultivar LS-89. Plant Pathol. 2017, 66, 150-158. [CrossRef]

30. Konappa, N.M.; Maria, M.; Uzma, F.; Krishnamurthy, S.; Nayaka, S.C.; Niranjana, S.R.; Chowdappa, S. Lactic acid bacteria mediated induction of defense enzymes to enhance the resistance in tomato against Ralstonia solanacearum causing bacterial wilt. Sci. Hortic. 2016, 207, 183-192. [CrossRef]

31. Francisco, C.S.; Ceresini, P.C.; Almeida, R.P.; Coletta-Filho, H.D. Spatial genetic structure of coffee-associated Xylella fastidiosa populations indicates that cross infection does not occur with sympatric citrus orchards. Phytopathology 2017, 107, 395-402. [CrossRef]

32. Born, Y.; Fieseler, L.; Thöny, V.; Leimer, N.; Duffy, B.; Loessner, M.J. Engineering of bacteriophages Y2: dpoL1-C and Y2: luxAB for efficient control and rapid detection of the fire blight pathogen Erwinia amylovora. Appl. Environ. Microbiol. 2017. [CrossRef]

33. McCallum, E.J.; Anjanappa, R.B.; Gruissem, W. Tackling agriculturally relevant diseases in the staple crop cassava (Manihot esculenta). Curr. Opin. Plant Biol. 2017, 38, 50-58. [CrossRef]

34. Preecha, C.; Wisutthiphaet, W.; Seephueak, P. Occurrence of canker caused by Xanthomonas axonopodis pv. citri on Pummelo (Citrus maxima (Burm.) Merr.) Cultivar. Tabtimsiam in Nakhon Si Thammarat Province, Thailand and screening fungicides, antibiotics and antagonistic bacteria against X. $a$. pv. citri in vitro. J. Geosci. Environ. Prot. 2018, 6, 1-7.

35. Pawar, B.T.; Pandit, B.D. Antibacterial activity of leaf extracts of Ocimum sanctum L. against Xanthomonas campestris pv. Mangiferae indicae. Res. J. Recent Sci. 2014, 1, 291-294.

36. El-Amier, Y.A.; Al-hadithy, O.N.; Abdullah, T.J. Antioxidant and antimicrobial activity of different extracts obtained from aerial parts of Urospermum picroides (L.) FW from Egypt. J. Adv. Chem. Sci. 2016, 2, $299-301$.

37. Akbar, M.; Sherazi, I.N.; Iqbal, M.S.; Khalil, T.; Waqas, H.M. Antibacterial and antioxidant activities of slender amaranth weed. Planta Daninha 2020, 38, e020192974. [CrossRef]

38. Simonetti, G.; Pucci, N.; Brasili, E.; Valletta, A.; Sammarco, I.; Carnevale, E.; Loreti, S. In vitro antimicrobial activity of plant extracts against Pseudomonas syringae pv. actinidiae causal agent of bacterial canker in kiwifruit. Plant Biosystems-An Inter. J 2019, 154, 100-106. [CrossRef]

39. Padmashree, M.S.; Roopa, B.; Ashwathanarayana, R.; Naika, R. Antibacterial properties of Ipomoea staphylina Roem \& Schult. plant extracts with comparing its preliminary qualitative phytochemical and quantitative GC-MS analysis. Trop. Plant Res 2018, 5, 349-369. [CrossRef]

40. Xia, R.Z.; Liu, S.Q.; Xie, Y.; Zhang, Y.; Wang, C.; Yin, W.; Liao, X.L. Antibacterial activity of Amaranthus tricolor extracts against five phytopathogenic Bacteria. Egypt. J. Biol. Pest Co. 2016, 26, 157-162.

41. Kiplimo, J.J.; Koorbanall, N.A.; Chenia, H. Triterpenoids from Vernonia auriculifera Hiern exhibit antimicrobial activity Joyce Jepkorir. Afr. J. Pharm. Pharmacol. 2011, 5(8), 1150-1156. [CrossRef]

42. Radhakrishna, S.; Kumari, P.S. GCMS Analysis of total terpenoids from Baliospermum montanum and its antimicrobial activity. J. Adv. Res. Appl. Sci 2018, 5, 94-101.

43. Fingolo, C.E.; Santos, T.; Filho, M.D.; Kaplan, M.A. Triterpene esters: natural products from Dorstenia arifolia (Moraceae). Molecules 2013, 18, 4247-4256. [CrossRef]

44. Díaz-Ruiz, G.; Hernández-Vázquez, L.; Luna, H.; Wacher-Rodarte, M.; Navarro-Ocaña, A. Growth inhibition of Streptococcus from the oral cavity by $\alpha$-amyrin esters. Molecules 2012, 17, 12603-12611. [CrossRef]

45. Chung, P.Y.; Chung, L.Y.; Navaratnam, P. Transcriptional profiles of the response of methicillin-resistant Staphylococcus aureus to pentacyclic triterpenoids. PLoS ONE 2013, 8, e56687. [CrossRef] [PubMed]

46. Chung, P.Y.; Chung, L.Y.; Navaratnam, P. Potential targets by pentacyclic triterpenoids from Callicarpa farinosa against methicillin-resistant and sensitive Staphylococcus aureus. Fitoterapia 2014, 94, 48-54. [CrossRef] [PubMed]

47. Broniatowski, M.; Mastalerz, P.; Flasiński, M. Studies of the interactions of ursane-type bioactive terpenes with the model of Escherichia coli inner membrane-Langmuir monolayer approach. Biochim. Biophys. Acta 2015, 1848, 469-476. [CrossRef] [PubMed] 
48. Li, X.; Zhang, J.; Gao, W.; Wang, H. Study on chemical composition, anti-inflammatory and anti-microbial activities of extracts from Chinese pear fruit (Pyrus bretschneideri Rehd.). Food Chem. Toxicol. 2012, 50, 3673-3679. [CrossRef]

49. Fernandes, C.P.; Correa, A.L.; Lobo, J.F.; Caramel, O.P.; de Almeida, F.B.; Castro, E.S.; Rocha, L. Triterpene esters and biological activities from edible fruits of Manilkara subsericea (Mart.) Dubard, Sapotaceae. Biomed. Res. Int. 2013, 280810. [CrossRef]

50. Zheng, Y.; Huang, W.; Yoo, J.G.; Ebersole, J.L.; Huang, C.B. Antibacterial compounds from Siraitia grosvenorii leaves. Nat. Prod. Res. 2011, 25, 890-897. [CrossRef]

51. Waqas, H.M.; Akbar, M.; Iqbal, M.S. Antibacterial and antioxidant activities of Agaricus bisporus (J.E. Lange) Imbach from Pakistan. Bangladesh J. Bot. 2019, 48, 1075-1081.

Sample Availability: Samples of the compounds are available from the authors.

(C) 2020 by the authors. Licensee MDPI, Basel, Switzerland. This article is an open access article distributed under the terms and conditions of the Creative Commons Attribution (CC BY) license (http://creativecommons.org/licenses/by/4.0/). 